\title{
Urban Infrastructures and Sustainable Social Practices
}

\author{
Ralf Brand
}

Sommer 1969

\section{6}

F you want your subordinates to do or not to do certain things, build a city" Machiavelli might have recommended to his prince. Indeed, there are numerous historical examples of purposively designed urban technologies and infrastructures that (are meant to) facilitate or prevent certain behaviors. Numerous authors have discussed, some even explicitly recommended, this strategy. Norberg-Schulz, for example, talks about "physical control" through built forms, Brodey praises "intelligent environments," and Sommer endorses "design for behavior change." While Lipman (quoted in Joerges) considers the behavior of people as "determined by the physical environment," Becker and Keim see the urban environment more cautiously as a "potential impulse for collective behavior." Moos is ready to utilize this mechanism: "The design of environments is. . probably the most powerful technique to influence behavior."

As the dates of these publications indicate, the 1960s and 70s witnessed a wave of ideas related to what may be summarized as "social engineering" or "environmental programming." Since then, many of these approaches have been stripped of their mechanistic naïveté, often under active contribution of authors in the field of Science and Technology Studies (STS) who emphasize the two-way-nature of the relationship between technologies/ infrastructures on the one hand and human behavior on the other. Perhaps the most prominent metaphor for this view is Hughes'

Journal of Urban Technology, Volume 12, Number 2, pages 1-25.

Copyright (C) 2005 by The Society of Urban Technology.

All rights of reproduction in any form reserved.

ISSN: 1063-0732 paper/ISSN: 1466-1853 online

DOI: $10.1080 / 10630730500307128$ 
term of a "seamless web" with society and technology constantly interacting and shaping each other.

The observation that the built environment exerts a gravitational pull upon behavior, often called "prescription," "domination," or "temptation" by STS scholars, is nevertheless one thread of the seamless web. If certain urban forms and infrastructures indeed manage to confine, enforce, or suggest a corridor of behavioral choices, this might raise the attention of sustainability activists who advocate large-scale behavioral changes through education, incentives, or-for that matter- "prescriptive" infrastructures. Apart from normative democratic qualms one could have with such an approach, its long-term effectiveness is not at all guaranteed. In other words, it is unclear whether we, designers and providers of urban infrastructures, should contemplate the temptation to make people do what they ought to do. If there are democracy-compliant paths to achieve this, it is far from evident where and how those paths are and what tools and techniques we have to bring along. Lacking the possibility of conducting experimental studies, I will analyze a number of historical examples for lessons regarding behavior and the built environment. I will also present a more recent case of what seems to be a legitimate and successful exemplar of Design that influences Social Practices, henceforth abbreviated as DiSP.

\section{Glimpses at Historical Cases}

A very interesting attempt to influence a citizenry's behavior is unfortunately not accessible to empirical assessment because Amaurot (see Figure 1), Thomas More's (1478-1535) ideal and (programmatically termed) "utopian" city, has never been built. Its design was supposed to stimulate orderly behavior and maximize the efficiency of interpersonal interactions. It is thus an early example of an explicit approach trying to improve the world not by preaching to the people or by legal coercion but by influencing people's behavior through design.

More 1999

A particularly blunt idea of social determination through urban infrastructures was implemented by order of Cardinal Del Monte (1487-1555), governor of Gualdo Tadino in Umbria, Italy: "When [he] saw popular sentiment against the Papal State swell dangerously, he had a spine of houses built in haste down the middle of the main square, dividing it in two and thereby diminishing the space, and effectiveness, of a possible uprising." 


\section{FIGURE 1}

\section{Section from Thomas More's Amaurot}

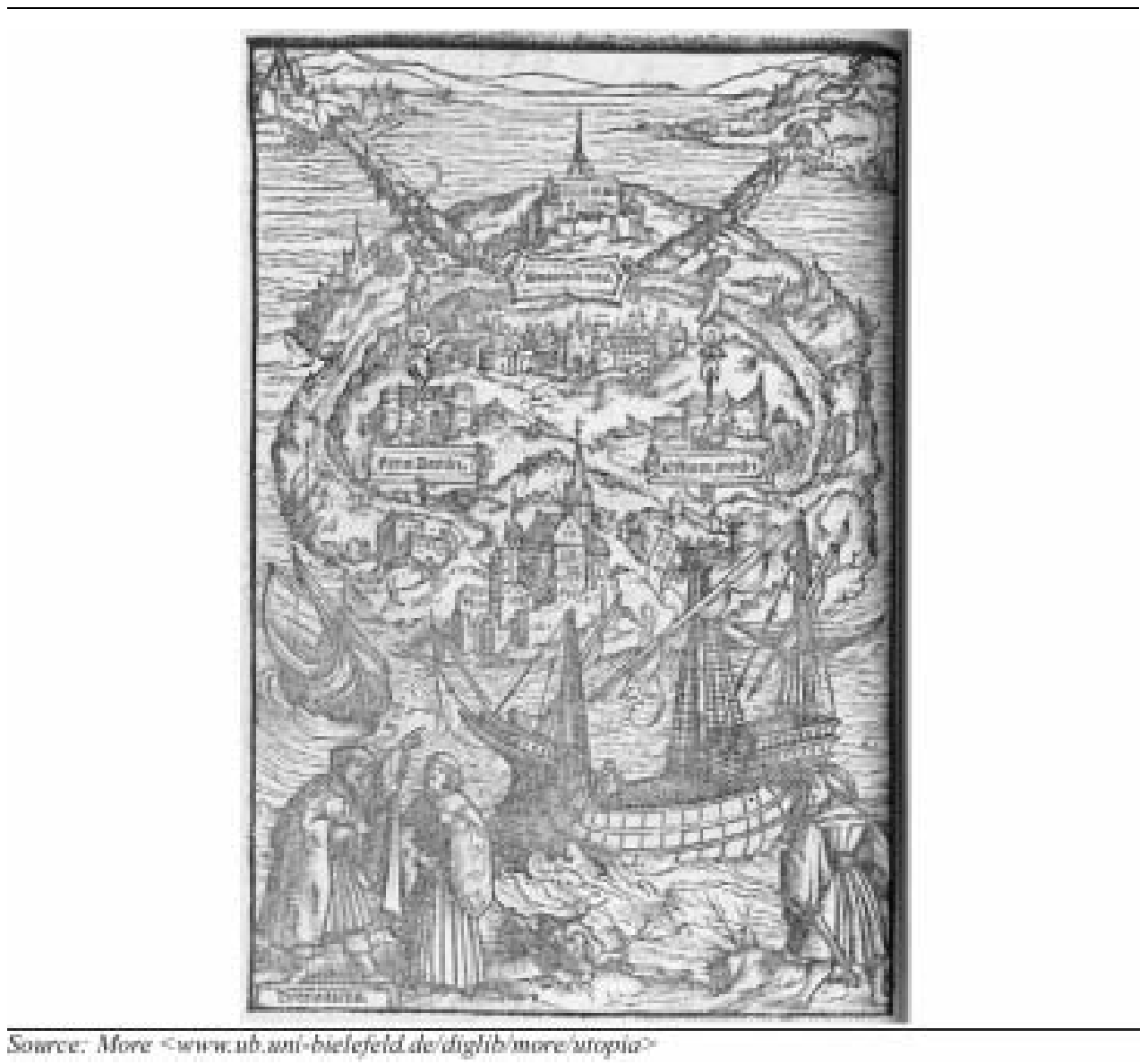

No information could be found on the success of Del Monte's coup; the fact that he later became Pope Julius III, however, seems to indicate that it did work quite well. What remains as counterargument must, therefore, be based on normative democratic foundations.

The Panopticon (literally: "all seeing") of Jeremy Bentham (1748-1832) is a classic example of deliberate control by design, particularly of prisoners. The original Panopticon was circular with the cells for the inmates built into the curve of the circle facing inward and thus open to observation from the guard tower located in the center. (See Figure 2.) Bentham's idea was that the constant possibility of being watched would coerce the prisoners to permanent compliant behavior. Bentham's model has made a considerable career as some penitentiaries have actually been built according to this design. Also, modern surveillance cameras follow the same principle of "seeing without being seen" and they, too, require far-reaching design consequences 


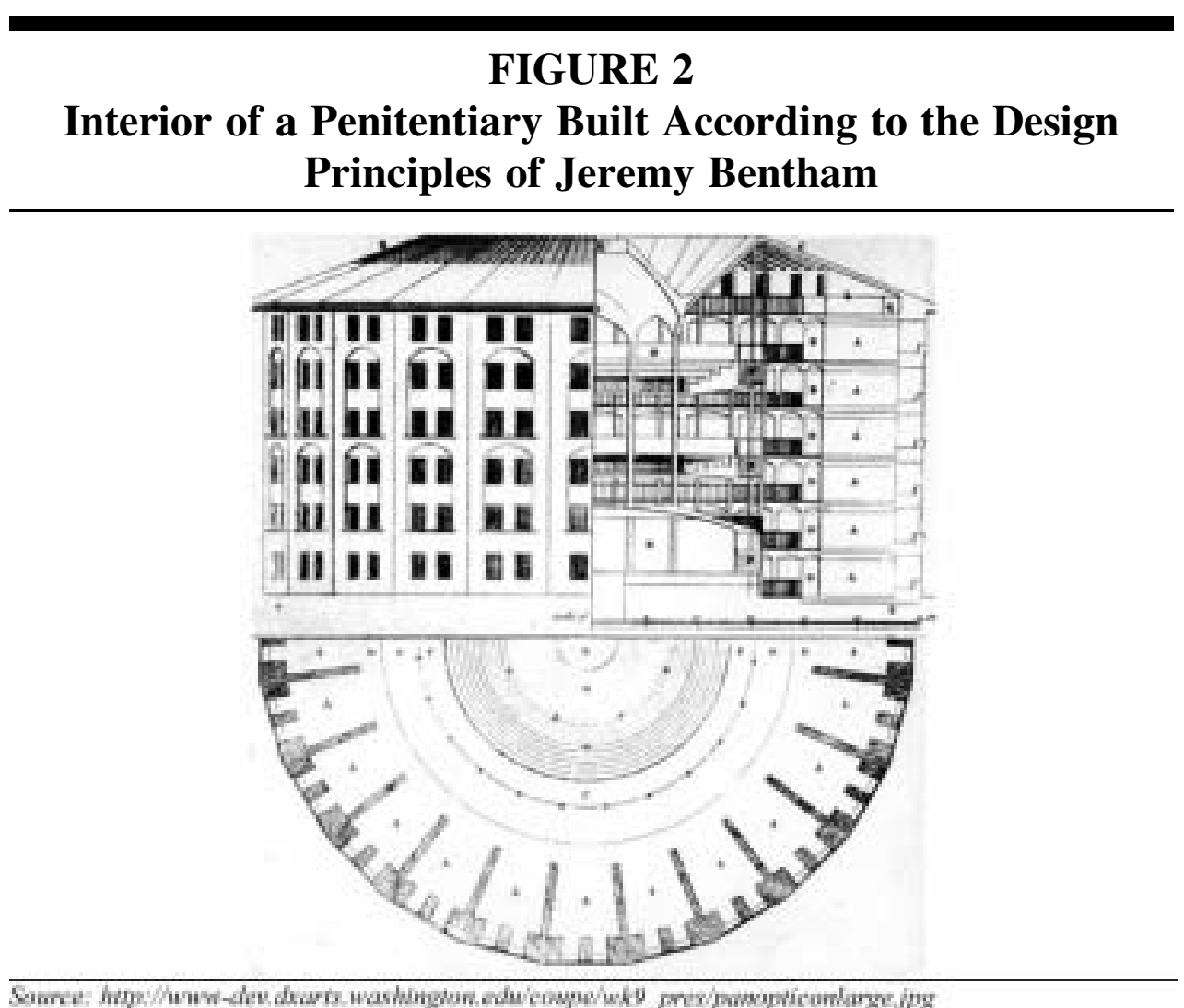

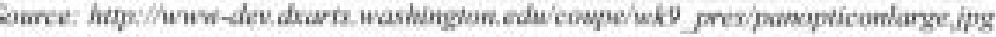

because public spaces must not contain corners and niches that elude the gaze of the cameras. Although John Stuart Mill considered himself a matured follower of Bentham's utilitarianism, he criticized its patronizing implications and its ignorance of the "existence of a consciousness, self-respect,... .honor and personal dignity." From a non-normative point of view, it is interesting, or almost fascinating, how petty criminals have learned to erode the effectiveness of constant observation by wearing out the alertness of the security personnel behind the surveillance monitors through week-long suspicious but lawful behavior before they actually strike.

In the early nineteenth century, unwelcome Anglo-Americans began pouring into New Orleans, a city dominated by the French/ Spanish Creoles who had settled there earlier. In order to prevent hostilities between the two social groups, an urban design proposal was put forth - a plan for a 50-foot-wide canal, with 60 feet of reservation on either side that was meant to separate the Anglos from the Creoles. The canal plans came to nothing, but the space reserved for it left a 170-foot-wide void in the center of New Orleans. A photograph from around 1867 (See Figure 3.) still renders the separating function palpable even after Canal 


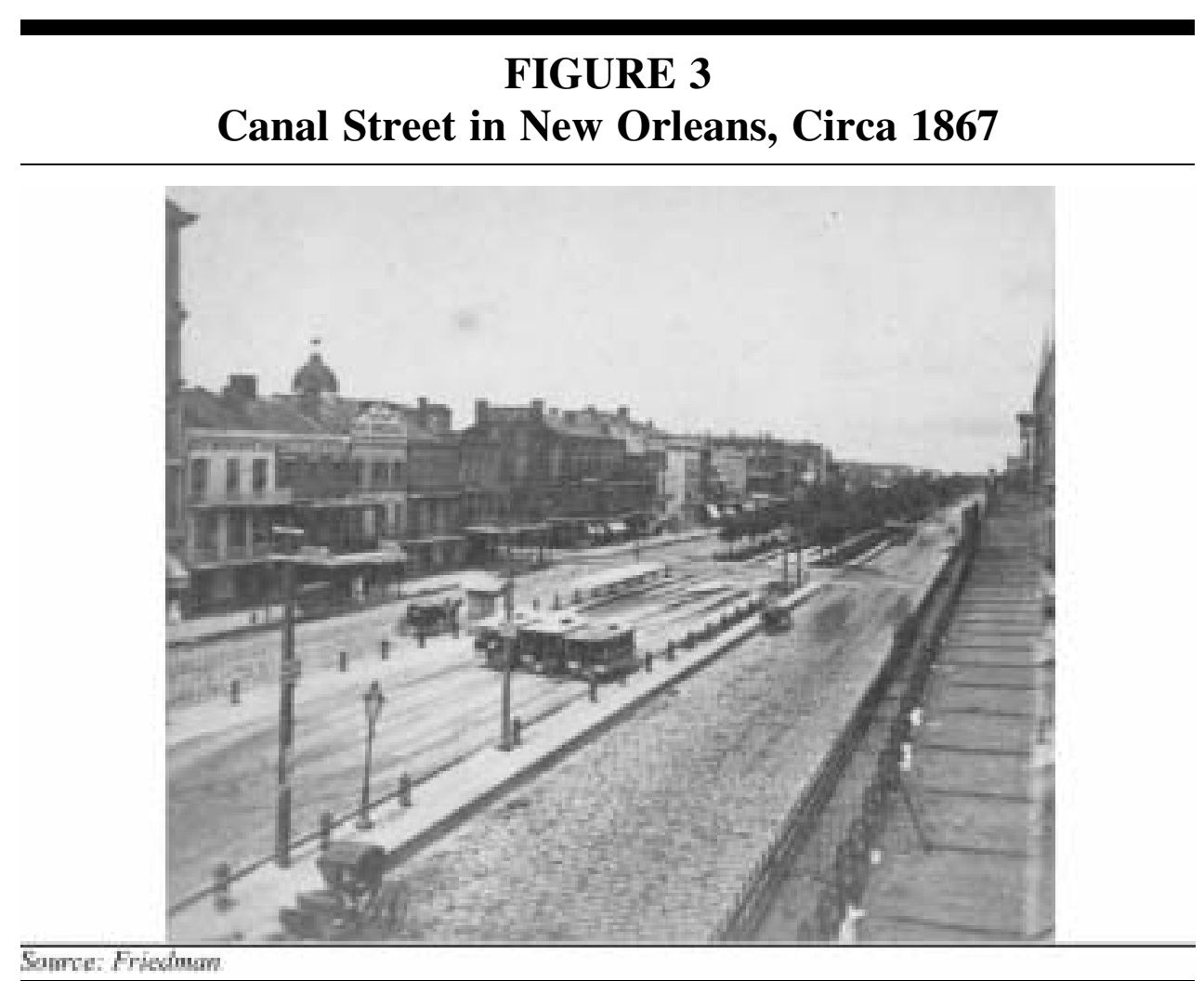

Street had long evolved into the bustling Central Business District. The initial "sociofugal" intention was thus outdeveloped by pragmatic economic rationales. Nevertheless, today's New Orleanians still refer to the former no-man's-land as the "neutral ground" and it remains to be wished that similar processes make much more rigid structures of separation, such as the walls in Belfast and through the West Bank, obsolete.

Robert Moses, the famous planner of New York City of the 1930s through the 1950s, is said to have employed a much more subtle strategy to keep social groups apart. He supposedly tried to keep the beaches of Long Island free of low-income groups, particularly of African Americans, by blocking buses, their preferred or only means of transportation, through low-clearance bridges. Although the intentionality of this design is subject to spirited debates in the STS community, it serves well as an exemplar of a school of thought that considers the architect "not as decorator but as organizer of life." In this view, the authorship of artifacts comes with enormous power to infringe upon the freedom of choice. Putting normative democratic worries aside for the moment, the pragmatic question remains whether such strategies succeed. In many, if not most cases, the patronized human objects circumvent the strategies by means of some form of 
subversion, disobedience, modification, sabotage, counterstatements or antiprograms. The low-income population of New York, for example, simply took the train to Long Island.

Modernist ideologies expected this permanent back-andforth of action, re-action, re-re-action and so forth to subside in an ideal city. One of them, the Voisin quarter of Paris (See Figure 4.), rose in 1925 on the drawing table of Le Corbusier who had envisioned it as the perfect city with minimized distances, thus making it obsolete for the citizens to reflect upon their mobility choices because the enlightened designer had already done the thinking - and the choosing. This approach was not meant primarily as an attempt to impose certain behaviors upon the users of built environments but rather as a method to finally facilitate truly rational behavior that was very cumbersome ${ }^{1}$ under the constraints of urban structures accrued from continuous ad-hoc additions to their medieval nuclei. The resulting tabula rasa approach in cities like Brasilia was expected to leap forward on the "proper path" of architecture and thus to draw nearer to an end of history. Later assessments, however, had to acknowledge that this modernist ideological program could not vitiate (a modified version of) McLuhan's seminal observation: "First we shape our cities and they in turn shape us." ${ }^{2}$ The "boring hygiene" of

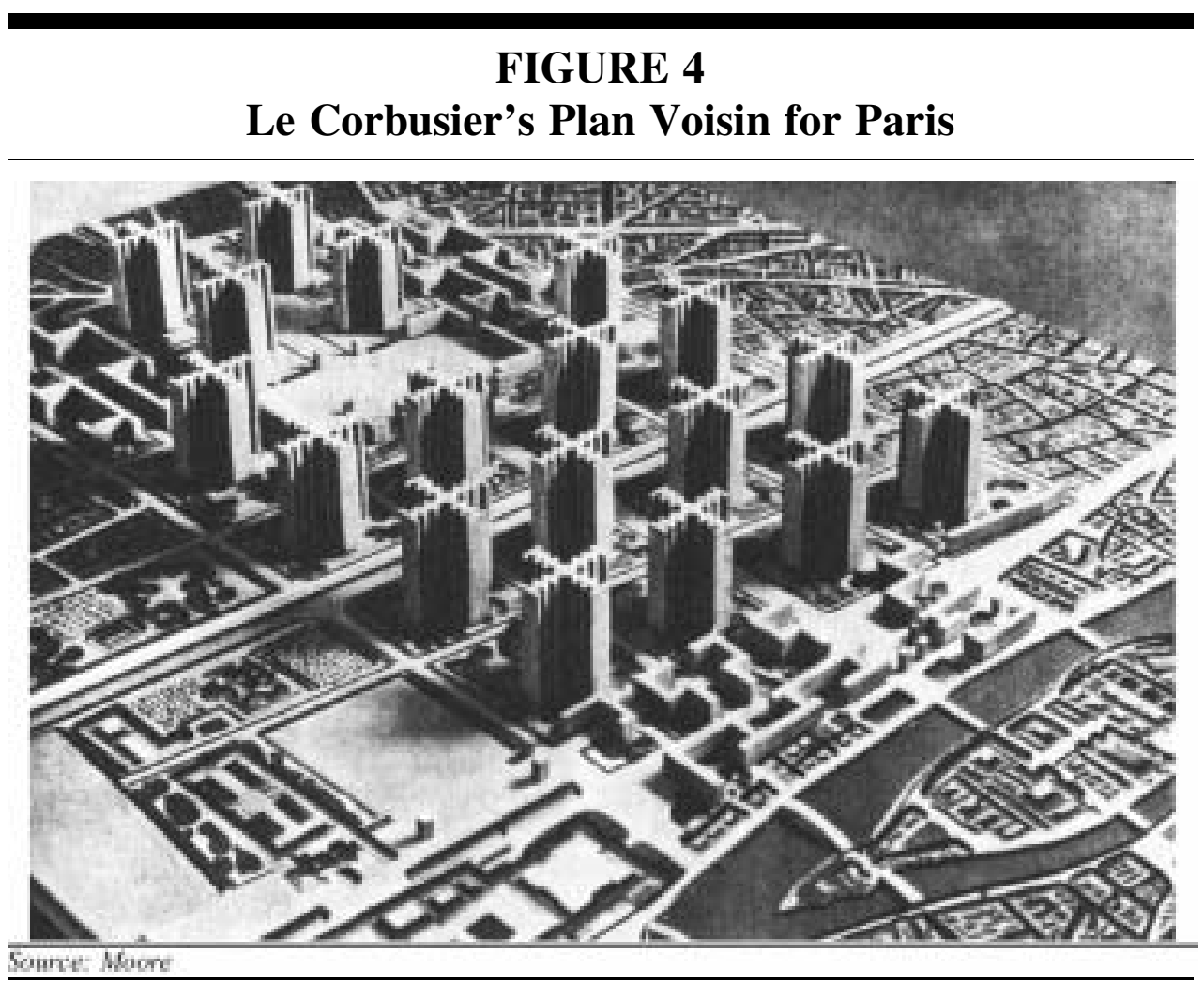

Pfaffenberger

Latour 1992

Joerges "Brücken, Busse. .."

${ }^{1}$ The Athens Charter, devised at the 1933 meeting of the Congrès Internationaux d'Architecture Moderne (CIAM), thus promised liberation from the "merciless force of customs" (CIAM).

${ }^{2}$ McLuhan said "tools" instead of "cities" (cited in Lapham p. xxi). Interestingly, Winston Churchill made the same point with a more direct relevance to the built environment: "We shape our dwellings, and afterwards our dwellings shape us" (cited in The Churchill Centre). I was unable to find out which man inspired the other.

Le Corbusier

Knie and Marz 
these cities molded their inhabitant to "a sanitized peasant on a chess board; but he is alone and there is no challenge, no dialogue." Lewis Mumford would have described this problem as a lack of "social drama" but he, too, saw the remedy in intentional design, in particular in "deliberate local nucleation,... better technical organization. . appropriate individual and urban structures." This idea culminates in Fishman's creed that architecture shall "direct the community onto the path of social harmony." One such strategy was employed in post-WWII Germany where "public places were not fostered in spatial planning due to their disreputed role as parade grounds."

The regime that had led Germany into World War II applied similar strategies to make people do what they ought to do and joined in the roundelay of most political ideologies that claim to know the truly best behavior, or simply define it according to their needs. The need was a large Aryan population for the "Lebensraum in the East" where Gottfried Feder, the Nazi commissioner for settlements, envisioned perfect cities with 20,000 inhabitants because a research project conducted by him found that Germans in medium-size cities procreate more willingly than in large cities. Figure 5 from Feder's famous book, Die

Feder Neue Stadt portrays this finding in a dramatic depiction, evoking the biological Volkstod (death of a people) in cities over 100,000 inhabitants where every household, on average, "produces" only 0.2 children. The Nazis found support for this supposedly objective finding in empirical studies by Heini Hediger, the curator of the Zurich Zoo, who found that "if a captive animal were given too little, too much, or the wrong kinds of space, it

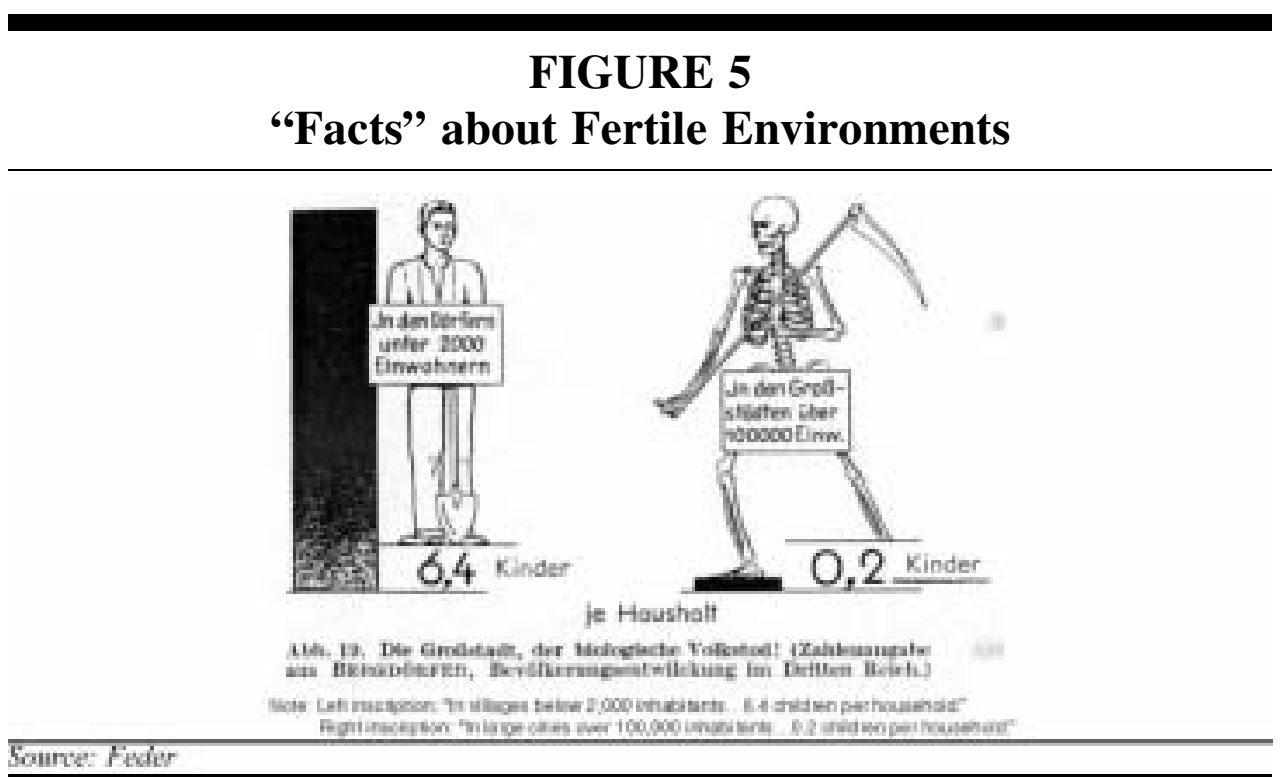


would be likely to...fail to reproduce." That the causal direction for the phenomenon observed by Feder might be reverse, that singles and people who wish to have fewer children choose to move to larger cities, did not interest his ideologically blinded opinion. Besides, he argued, large cities are "hatcheries of Marxism and Bolshevism [therefore] they are to be destroyed through decongestion and rehabilitation." An assessment of the effectiveness of Feder's approach is dispensable because its underlying absurd doctrines led to other political results that thwarted its implementation: Germany's defeat.

During the 1940s and 50s, General Motors (GM) pursued its vision that people ought to use cars instead of public transport by influencing the design of urban infrastructures. In one case, for example, GM created "front" companies to acquire the majority of shares of public transport companies in East Bay, San Jose, Fresno, Stockton, Sacramento, San Diego and Los Angeles (for a detailed analysis see Szoboszlay and Snell). These hostile takeovers, as we would call them today, allowed GM to slowly but surely allow the rail-bound public transport system to deteriorate. Although a 1948 official report concluded that "electric interurban railways have a greater capacity and offer safer and faster transportation. . than do other forms of transportation," the electric trains and streetcars were replaced by GM buses and the rights of way of the trains were converted to additional automobile lanes. This coup was eulogized as "modernization" (See Figure 6.) but was effectively "a tool for discouraging people from using transit [because] buses have absolutely no advantage over streetcars and trains from the customer's viewpoint." Eventually, people voted with their feet as a letter to the editor states in 1948: "Every month more and more of us are being driven from the Key System [the public transport system in the East Bay area] to the use of private automobiles." As we know in retrospect, this attempt to influence people's behavior was terribly successful and left an enormously unsustainable legacy.

Crime Prevention Through Environmental Design (CPTED), an approach that emerged in the 1970s, tried to prevent people with criminal energies from doing what they ought not to do. The basic premise of CPTED and its more academic branch, Environmental Criminology, is "that the physical environment can be changed or managed to produce behavioral effects that will reduce the incidence and fear of crime." In other words, it "aims to reduce the opportunity for specific crimes to occur" through deliberate arrangements of the built environment.

California Department of Public Works

Szoboszlay

Szoboszlay

Draper

International Security

Management. . . 
FIGURE 6

Advertisement in the Oakland Tribune January 23, 1948

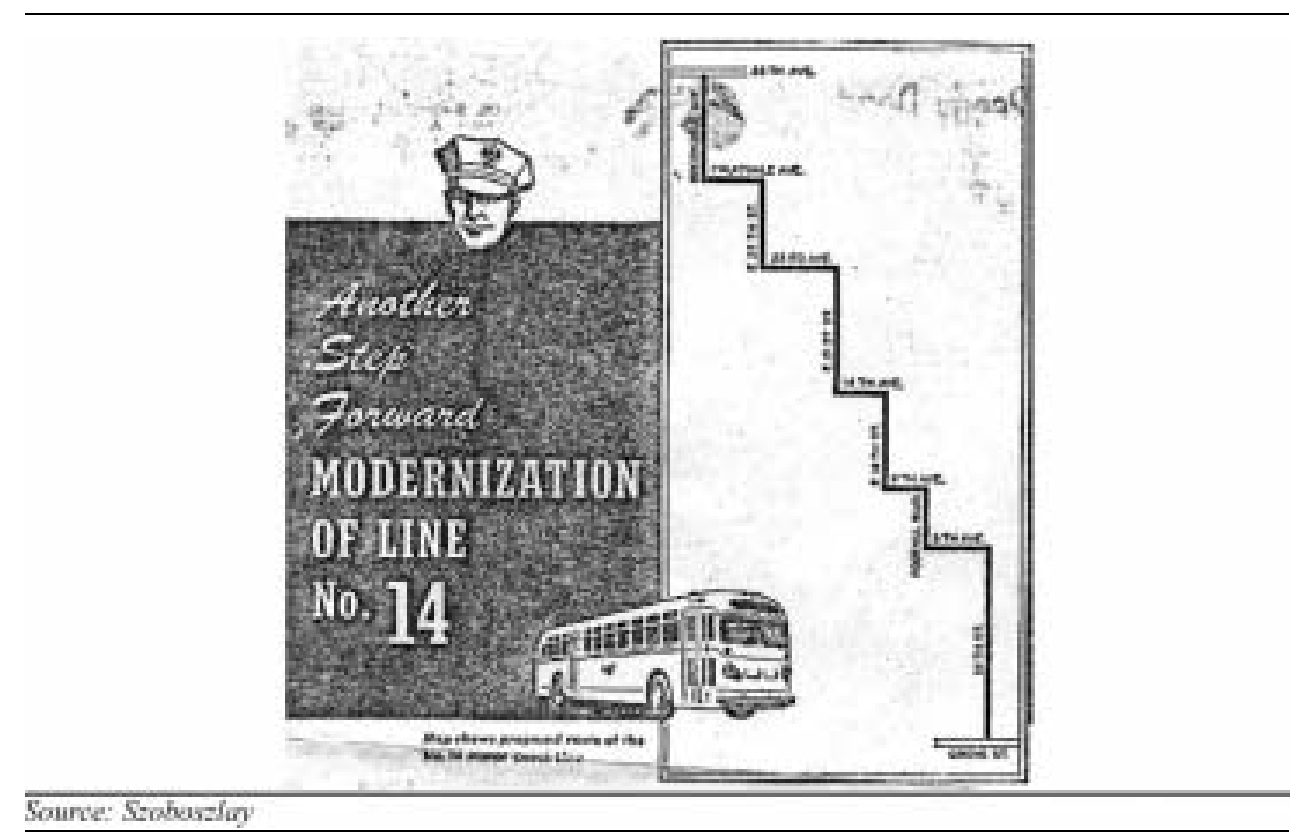

Figure 7 shows an example of a neighborhood designed according to CPTED principles. ETTA Training, an Australian training provider for engineers, describes other CPTED applications such as:

street lighting, sensitive landscaping, and windows to improve opportunities for surveillance, increasing the frequency of use of under-utilized (hence potentially dangerous areas) by introducing facilities such as stores and recreation facilities, using low scale fences or shrubbery to indicate that a particular piece of property belongs to residents of the site.

While there certainly exists some kind of "CPTED tunnel McKay 2004 vision" that enthusiastically embraces CPTED as a panacea against all evil, the assessment of ETTA Training does not seem terribly exaggerated that CPTED is a "proven approach to reducing. . .opportunist crime."

Another set of approaches without a particular label attempts to influence the behavior of ordinary, law-abiding citizens through built forms. Chains or railings, for example, are supposed to discourage jaywalkers while elsewhere, designers "seek to channel jaywalkers by using a mid-block crosswalk." Cobblestones, speed bumps, street narrowing, and other features of the "selfschmitt explaining street" are supposed to prevent motorists from speeding. More positive incentives are needed for the 


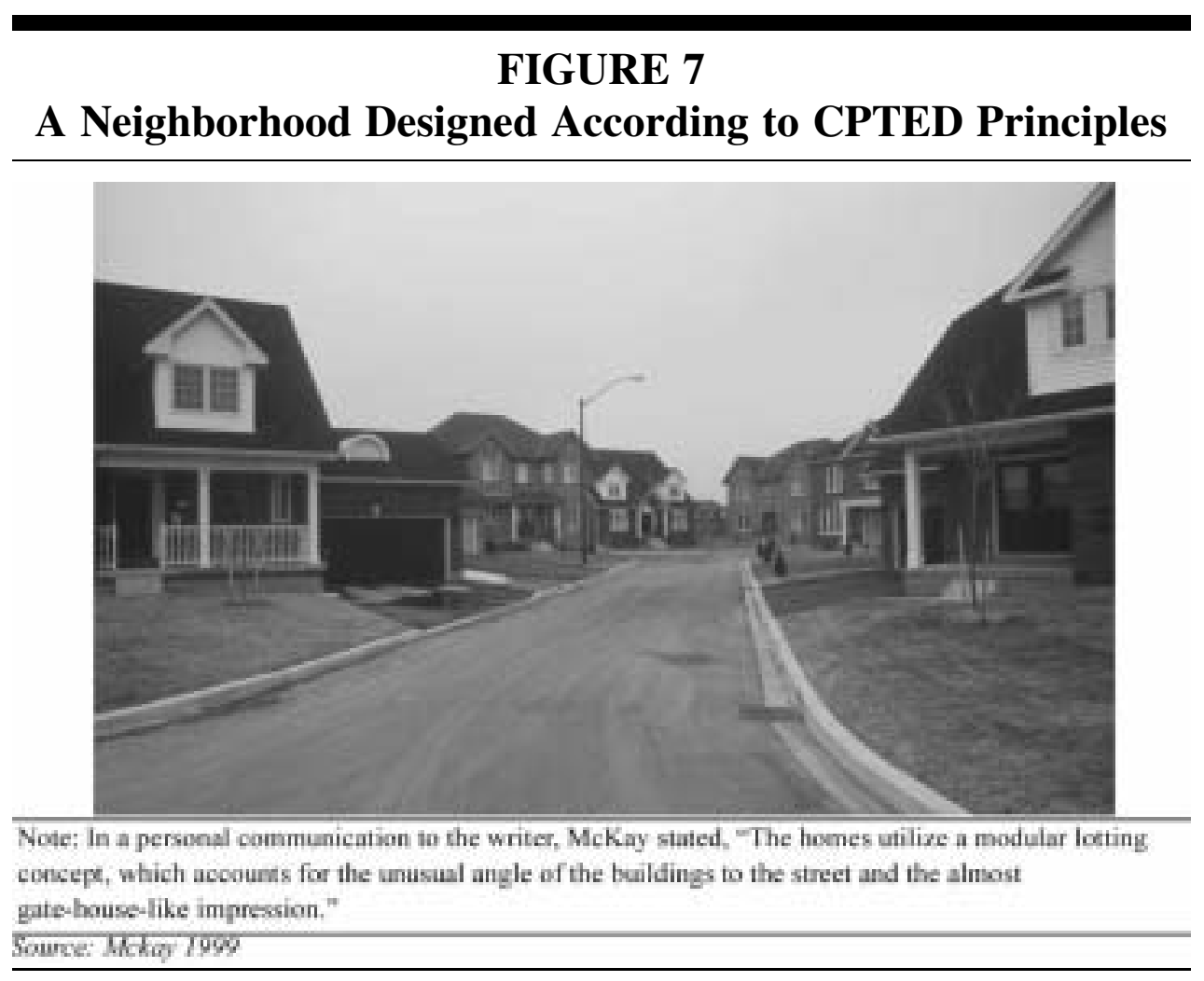

"merchant-friendly streetscape-design," which is a never-ending Brodeur task for planning consultants. Brodeur, for example, recommends finding the right balance between too little and too much illumination (insecurity versus ballpark atmosphere), providing the right amount, type, and location of parking spaces, and segmenting the sidewalk into three distinct zones (utility, throughway, and browsing) with the latter generating the perfect setting for allowing window-shoppers to stop and gaze. The desire to induce potential customers to linger in the shopping district also made the Belgian city of Hasselt replace spiky, anti-parking poles with flattened ones because tired shoppers can rest on the latter. I know of no universal assessment of the effectiveness of such techniques, but from anecdotal evidence it seems fair to conclude that many of them work pretty well as long as the users do not feel too bluntly manipulated and approve of the greater purpose of the measures taken.

The mobility policy of Hasselt provides another contemporary example of how urban technologies and urban design can influence social practices. The city used to suffer from severe traffic-related problems such as accidents, traffic congestion, restricted mobility for senior citizens, and poor accessibility to the shopping district in the city center especially for out-of-town customers. In the mid 1990s the city council opted to narrow the 
traffic artery in the inner city; convert the space thus gained into parks and bicycle and pedestrian lanes; increase public transport services eight-fold; radically modernize its bus fleet; introduce a five-minute interval on some bus routes; and make bus travel free of charge. As a result, many people changed their behavior, such that bus use increased eight-fold. These changes in social practices were achieved not through moralizing awareness campaigns but through urban infrastructures that made the socially desired behavior (walking, bicycling, and bus use) convenient.

\section{Disentangling the Evidence}

For a provisional conclusion, Skinner's observation does not seem completely absurd that "there are many varieties of 'behavior modification' and many different formulations, but they all agree on the essential point: behavior can be changed by changing the conditions of which it is a function." The founder of Behaviorism goes even further and argues that if all stimuli are set right "people will become wise and good without trying, without having to be, without choosing to be. The application of behavioral science to moral training will produce men who are good practically automatically." This view of human beings as rats in a moralization maze must sound repulsively Orwellian to those who favor democracy, including myself. However, I and many others also have other ideals that call for some kind of design to influence social practices toward, in my case, sustainable development. One immediately self-suggesting question could thus be whether the ends justify the means. I agree with Healey, however, that planning Healey debates should move "beyond utilitarianism," which is why I deny the primacy of this question and instead suggest to start with an investigation of whether the means have to be Orwellian and what makes them Orwellian. In order to approach an answer to these intertwined questions, I propose to disentangle the heap of evidence provided in the above cases into two broad categories: The content of DiSP (Design that influences Social Practice) projects on the one hand and their development processes on the other.

\section{Content}

One can differentiate DiSP cases according to the rigor of their embodied scripts. DiSP projects can either be rigorous in the sense that they leave no other choice but to obey the script built into an artifact or they can simply suggest a certain behavior. 
The STS community uses the expressions domination, prescription, constriction, or determination for the former type. Rigorous scripts enforce the desired behavior by ruling out its alternatives and leaving only a narrow corridor of behavioral choices; for example, a car that does not start unless the driver is buckled up. The second type of DiSP is laxer and simply suggests to do or not to do certain things but still leaves realistic alternatives, like the flattened anti-parking poles. A commonly related but not identical criterion is based on Giddens' idea of a "duality of structure" and separates cases that discourage from those that encourage certain behaviors. The former type deters from undesired choices by making them unattractive (not necessarily impossible) and is widely debated in the STS literature-maybe because it triggers indignation and thus attention. But in contrast to the behavior-fugal case (i.e., a design that discourages or prevents undesired behaviors) are behavior-petal cases (i.e., designs that make desired behaviors attractive). Latour reminds us that there are artifacts that are "generous." He says, "thanks to them...we are 'allowed,' 'permitted,' 'enabled,' 'authorized' to do things." Their designers try to make the desired behavior convenient, thus hoping to invite or lure their users toward certain choices. Most frequently, rigorous DiSP projects are behavior-fugal because it seems to make more sense to harden the walls of a narrowed corridor of choices (behavior-fugal) than to leave open a deliberately widened one (behavior-petal).

The underlying philosophy, especially of rigorous and behavior-fugal DiSPs, is plain mechanistic. It considers human beings from a behaviorist angle as machines that merely react to stimuli. The challenge of creating a good world is in principle seen as a two-variable problem with the environment-including the natural, social, and built environment-being the independent and social practices being the dependent variables while "neglecting the minor influence of other factors" as Weaver is quoted in Jacobs. This notion of a linear simplicity represents, in his view, one of three core strands in the history of modern thought- the others are disorganized complexity and organized complexity and will be addressed further below.

The usefulness of Weaver's classification for the urban planning discipline has been explicated in Jane Jacobs' seminal book, The Death and Life of Great American Cities. Although this publication has already been read by over one generation of planners and architects, it has not lost its inspirational value. It has actually gained new importance in the context of sustainable 
development, which is the angle from which I re-ask Jacobs' question about "The Kind of Problem a City Is"- -the title of her book's final chapter. Therein she uncovers the mechanistic and deterministic ontology of planners who consider and treat cities as problems of simplicity. Cardinal del Monte's decision to build a spine of houses through the plaza of Gualdo Tadino is a prime example of this strategy. Rigorous and behavior-fugal approaches do not, in general, allow or provide for alternative behaviors and thus create what Sennett laments as purified and excessively ordered cities in which "diversity and vitality [are] destroyed by powerful architects and city planners." These designers cultivate the typically modernistic arrogance of knowing the universal solution, even the universally correct behavior thus creating monocultures of social practices. Everyone who shares Sennett's understanding of the "essence of urban culture...[as] the possibility for living in difference" will, therefore, consider rigorous and behavior-fugal DiSPs as anathema. Yiftachel, too, is a fervent champion of urban diversity as can be seen from the title of his publication "The Dark Side of Modernism: Planning as Control of an Ethnic Minority." Patsy Healey's empirical research shows that "social ordering concepts of dominant groups embedded in plans and regulations. . . [impair the] capacity to innoHealey vate" thereby vitiating the capability of "adjusting to complexity," which has come to be a matter of survival in our globalized times.

But not all DiSP cases start from the assumption that cities are problems of simplicity. Cities can also be seen as problems of disorganized complexity, to tie in with Weaver and Jacob's classification. This strand of thought moves from two to a myriad of variables, which interact in a disorganized manner in a highly complex system. Mathematical and methodical advances in the early twentieth century helped us to "manage those phenomena as statistical averages without knowing much about the actual interactions." Feder and Corbusier are typical of those who neglect details. They treat the city as a large billiard table with thousands of balls that seem to create a system with certain orderly and analyzable average properties. Jacobs' analysis revealed how the designs of many modernist planners - explicitly including Le Corbusier's ideological heir, Robert Moses-rest upon the ontological assumption of disorganized complexity and the corresponding notion of large statistical populations. In this framework

Citizens...could be dealt with intellectually like grains of sand, or electrons, or billiard balls...[and cities became] 
understandable purely by statistical analysis, predictable by the application of probability mathematics, manageable by conversion into groups of averages.

Jacobs 1961

These ideas brought us the notorious urban renewal projects from the 1950s through the 1970s that were often meant as behavior-petal deeds to enable truly rational behavior which was troublesome under the previous messy urban structures. Arguments against these allegedly liberating projects were considered, as Weaver puts it, to be "in some dark and foreboding way, irrational." But because these seemingly chaotic but organically grown neighborhoods with all their productive diversity made perfect sense to many of their inhabitants, the attempts to brutally level them encountered increasing resistance. Robert Moses, for example, failed to push through two of his four suggested Manhattan expressways because of massive citizen protests. New York Assemblyman Louis DeSalvio hit the mark when he said of their opinion: "Too many of his [Moses'] dreams turn out to be nightmares for the city." It is, therefore, highly recommended to dismiss the attempt of benevolent designers to shape social practices with a disorganized complexity approach, be its manifestations rigorous or not, behavior-petal or not. This decision does not need to rest on normative grounds. Pragmatic counterarguments alone are strong enough because any DiSP attempt that is disapproved, boycotted, or undermined by "deviant" social practices is, by a very down-to-earth definition of sustainability, not able to be sustained-especially in a democratic society.

\section{Process}

When assessing the factors and forces behind a DiSP project, it is mandatory to examine the identity and interests of the designers. They can favor either the society at large or an elite class whose money pays their wages. This categorization might trigger charges that these observations are value laden, but it is first of all simply meant as a descriptive device. After all, it is no secret that Cardinal Del Monte, General Motors, Robert Moses' alleged friends with property on Long Island, and the downtown merchants were the intended initiators and beneficiaries of the respective projects. Regardless of which of these cases the individual reader considers legitimate, it is certainly worth noting that there is an inherent danger of misuse of power if DiSPs are designed to create benefits for their author(s). At the same time, 
it deserves mention that such a constellation is not necessarily illegitimate as the case of merchant-friendly design makes clear. What remains as lesson learned is, therefore, "merely" an encouragement to pay close attention to the fact that "artifacts have politics" as Winner exhorts.

But even when the society at large is the intended beneficiary, these cases permit no sweeping conclusion as proponents of a utilitarian ends-means arithmetic might have hoped. In their eyes, we should allow benevolent experts to "bite the bullet of technologiFeenberg cal reform... if a greedy populace shirks its duty." The problem of this position should become clear if we look at the abovementioned pro-society cases: The intended effect of New Orleans' canal, Corbusier's Paris, Feder's cities, CPTED, and Hasselt's mobility regime was to foster some common good-be it conflict avoidance, general efficiency, folkish hegemony, safety, or sustainability. One issue that makes these cases tricky is the dependence on benevolence which could turn into quite a risky gamble if designers only need to earn money but no votes. But even if we assume candid and continuing benevolence as a given, there remains the pragmatic issue of effectiveness because non-dictatorial DiSPs-and these are the only ones I intend to contribute to-are only effective, that is, sustainable, if they are aligned with the complex reality of their users' lifeworlds. Otherwise, they remain simply unused in the best case or they are undermined by defiant behavior, outsmarted, counteracted, or even sabotaged, in the worst. This raises important epistemological problems even for the most benevolent techno- and bureaucratic designer: In order to reach an alignment of the intended benefits with users' life-worlds, designers need to acquire and process knowledge about the immensely complex clockwork of everyday life, its intricacies and idiosyncrasies, and constraints and incentives that influence decisions and social practices. Their standard operational repertoire, however, is illsuited to accomplish this. Its two most common elements are specialized in reducing complexity either by treating cities as pro-

${ }^{3}$ This is the point where contentand process-related issues converge because they are indeed intertwined. Mehaffy "Codes and the Architecture of Life" blems of simplicity or as phenomena of disorganized complexity. ${ }^{3}$ But neither strategy allows designers to understand the effects of their products at the grassroots level where the decisions on social practices are made. Mehaffy calls this the "pedestrian experience" of master-planned buildings "where the detailing drops away in a mess of ugly concrete or poorly-weathering blank surfaces." These "relational effects [and] unintended consequences" are, in Wallman's words, "not normally anticipated 
in the planning [and] defined out of the planners' frame" through a convenient definition of system boundaries. But what matters in people's lives is not the system as delimited by analysts but the greater system of down-to-earth relevance. ${ }^{4}$ In Hasselt, this insight led to a host of measures in addition to, and in support of, the widely talked-about bus system and street remodeling: Guarded bicycle sheds were established because cyclist not only want safe routes but also a worry-free day in their office. They also need washing facilities after a cycle commute on a warm summer morning; therefore, the city launched a program to encourage companies to provide showers and cloakrooms. It also provides safety jackets, promotional pennants, stickers, and logistical support for the "Fietspool" program, in which adults volunteer to guide children from their neighborhood safely to their school. A thorough understanding of the many factors that influence one's mobility decision resulted in the installation of heated waiting areas with a real-time information system about expected bus arrival times, telephones, and clean restrooms. Shopping for pedestrians has been made less arduous in the inner city through the provision of baggage storage facilities and "plans are under way to provide shopping carts which can be taken anywhere in the shopping district." On their way home, bus users will be greeted by a friendly bus driver because all of them "received special training in public relations so that they could take care of the passengers instead of worrying about collecting fares." Friendliness and aesthetics are important factors of Hasselt's mobility policy-which is why the renowned architect Aldo Rossi has been commissioned to design the "Green Boulevard" along the inner ring road-but not ubiquitous in mainstream considerations about urban technologies, unfortunately so because "beauty has social consequences." We can, therefore, conclude that successful changes of social practices can only be effectuated through coherent improvements at strategic nexuses in the greater system of people's life-worlds.

The identification of these critical points and of the social mechanisms between them is unlikely to be achievable through the positivistic knowledge procurement strategy of technocrats like "formidable and impressive planning surveys...that come out with fanfare, are read by practically nobody, and then drop quietly into oblivion." It rather requires opening the black box into which modernistic planners prefer to contain the urban organism and to engage in almost anthropological interaction with people's life-worlds. It needs to be "focused around the concerns
Wallman

${ }^{4}$ Another project in Hasselt exploits this rationale: The city gives away official city flags as a means of encouraging citizens to clean their part of the sidewalk. At certain occasions, the mayor explains, "we can ask the people. . to put the flag at their house. And I think that people...don't fly a flag at their house and let the garbage stand in front of their door" (Stevaert).

Jacobs 1996

Ministerie van de Vlaamse Gemeenschap

Moore and Brand

${ }^{5}$ Sennett mentions another frequently applied strategy, which is at least as inappropriate for learning about the complexity of life-world realities: "One technique of planning large human settlements developed in the past hundred years has been the device of establishing 'projective needs' This means guessing the future physical and social requirements of a community or city and then basing present spending and energy so as to achieve a readiness for the projected future state" (Sennett). 
Jacobs 1961

Jacobs 1989

Jacobs 1989

Efremenko

Coaffee and Healey

of multiple daily lives [with an] appreciation of diversity" as Healey explains. Such an approach treats cities in exactly the way Jacobs recommends in the final chapter of her seminal book: "Cities happen to be problems in organized complexity." A system that displays characteristics of organized complexity is always more than the sum of its parts; it is an organic whole and it should not be surprising that suitable means for the analysis of

Weaver this type of problem have been developed in the life sciences. And cities are, just like living organisms, characterized by many variables that are "all varying simultaneously and in subtly interconnected ways...but they are not helter-skelter... and surely understandable." It is not sufficient in DiSP development processes to give those who are affected by design decisions a chance to comment on the drafts of ideologically or scientifically enlightened experts. The question is whether the experiences, assumptions, ideas, concerns, and dreams of those whose social practices will be a reaction to the new regime are regarded as resources instead of problems to be overcome. This process requirement is best met through meaningful participation before the arrow has left the bow in the development process of new technologies or infrastructures. This call resonates Efremenko's argument to move "up the participation ladder" which Arnstein devised as early as 1969. From its bottom end, citizens are seen as in need of manipulation or therapy. As we move up the steps, participation is considered a strategy of informing or placating people while at the desirable upper end of the ladder, it is seen as a form of partnership, a tool to delegate power and ultimately as a strategy to put citizens in control. While the effectiveness of citizen participation is primarily dependent on appropriately designed processes, it deserves mention that technologies can play a crucial supportive role in this regard. Public participation GIS, e-governance, mailing lists, document servers, meaningful URLs, and even cybercafés can facilitate effective participation. The design of these tools requires some kind of meta-participation to ensure that participation processes and tools are designed in a participatory way.

\section{Conclusions}

It is not uncommon among planning practitioners to pursue a technophilic approach to sustainable development, that is, to accept popular demands - such as the desire for unfettered cartravel-as givens and try to meet those demands with as little 
resource deployment as possible. Typical examples of this "tacit efficiency" approach are traffic-management systems that intend to maximize throughput without questioning the need for carbound travel. What advocates of this strategy tend to disregard is one of the main insights of STS research: That the currently prevailing social practices are contingent upon an historically grown regime of infrastructures, technologies, social expectations, legal frameworks, etc. This neglect turns unfortunate if the anthropogenic nature and hence the malleability of the prevailing regime remains unrecognized. And it would border on irresponsibility if planners overlooked that whatever they build today will be part of the regime that influences people's social practices tomorrow and for the next, who knows, 100 years. Mehaffy, too, warns us not to close our eyes to the undeniable gravitational pull the built environment exerts on social practices: "[W]e must somehow account for the fact that it [our architecture] will shape our use of resources and our patterns of interaction with each other....It shapes and conditions the emergent structures of human behavior-for better or for worse." We should, therefore, make the best of this phenomenon without moving to other extremes of technocratic manipulation, bureaucratic coercion, or "expertocratic" paternalism; not only because they are taboo for a democratic society but also because they are not necessarily successful-although they might be, as Cardinal del Monte could affirm. However, if brutality like the Cardinal's in suppressing counter reactions is rejected, the effectiveness of any DiSP can only rely upon its innate qualities. Two of the approaches described above were found to be unsuitable paths in pursuing DiSPs. Designers and planners who assume an inherent simplicity and immutability of the mechanisms that govern the relationship between the built environment and social practices claim to understand the underlying deterministic mechanisms but they are ill-equipped to discover and utilize the organized complexity, mutuality, and fluidity of these interactions. Their colleagues on whose ontological radar cities appear as problems of disorganized complexity do not claim to know much about the enmeshments in the seamless web. They trust in the statistical effect that their products will somehow change social practices. The direction of change, however, is accordingly difficult to steer. In addition, both approaches often cause severe collateral damage to the sophisticated subtleties of people's life-worlds and to the meanings they radiate.

Mehaffy "Codes and the Architecture of Life" 
The recommended strategy for the development of successful DiSPs is, then, to treat cities as problems of organized complexity. As demonstrated above, this requires a thorough understanding of people's life-worlds and the best method to achieve this is through what Gadamer describes as "fusion of horizons." This is not a gauging procedure by a detached investigator but a dialoguebased alignment of perspectives between the providers and users of urban infrastructures. During this process, the potentials for changes to regime elements and to social practices-as well as their mutual dependence - can be carefully articulated. Hunt and Wynne emphasize in this regard that "public opinion, or even individual standpoints, are not fixed and immutable, but change in relation to a number of factors." Shove offers a similar argument, saying that preferences and needs are not "stable and taken for granted [but rather] sociotechnically configured [and] immensely Shove malleable." The most succinct version of this observation comes from Healey: "[P]eople do not have fixed interests" (quoted in Fainstein). It is, therefore, indispensable to bring people, that is, the ultimate experts in user behavior, as co-designers into this negotiation and development process. Public participation is, of course, not a novel demand; it is a frequent, often mandatory, element in most processes that follow a logic of simplicity or disorganized complexity. However, people are usually admitted at a rather late stage of the process, most commonly after problems, questions, and goals have already been defined. In other words, participation is often an end-of-pipe exercise intended to stave off later resistance to the project. The reciprocal of the shortcomings of this approach are the potentials of the kind of public participation advocated here: A synchronic pre-alignment of the supply and demand side, a co-evolution of the technical and the social or, with Mehaffy, "an organic fusion between technology and human culture."

Such a process not only eliminates the risk of selfish or malevolent designers and minimizes opportunities for the misuse of power. It is also an ideal means to test the acceptability of DiSPs whose beneficiaries are identical with the designers as in the case of merchant-friendly streetscapes. Most importantly, participatory design maximizes the chances for success in the absence of brutality with success being defined as the facilitation of new social practices that are compliant with socially desired goals. If these goals deserve the label "sustainability" we as planners, architects, and engineers should go ahead and help employ design to facilitate the desired social practices. We should not, however, 
judge from afar what qualifies as "sustainable." This decision, too, has to be made at every locale anew as long as it improves any of the three commonly communicated pillars of sustainable development-economic viability, ecological integrity, and social equity-without eroding any of them. There is a clear criterion, however, to disqualify DiSPs from the sustainability certificate, namely, if it will trigger resistance that renders them ineffective and unable to be sustained.

Planning from process to content, I dare speculate that participatory DiSP development procedures will rarely lead to rigorous DiSPs, especially not to rigorous and behavior-fugal ones. The results might be suggesting and behavior-fugal but most likely they will be suggesting and behavior-petal. While I do not recommend steering the process in this direction, it is surely helpful for planners and architects to think through these categories and to convey them throughout their community as conceptual tools to grasp the range and types of options.

\section{Acknowledgments}

Special thanks to the organizers and participants of the International Summer Academy on Technology Studies 2004 in Deutschlandsberg, Austria-especially to Peter Wilding and Harald Rohracher-for their critical questions that helped me make the argument more robust. I am also grateful for the comments of the anonymous reviewers. 


\section{Bibliography}

S. Arnstein, "A Ladder of Public Participation," The Journal of American Institute of Planners 35:4 (1969) 216-224.

H. Becker and K-D. Keim, Wahrnehmung in der städtischen Umwelt: Möglicher Impuls für kollektives Handeln fourth edition (Berlin: Kiepert, 1978).

R. Brand, Co-evolution toward Sustainable Development: Neither Smart Technologies nor Heroic Choices (Ann Arbor, MI: UMI, 2003).

M. Brodeur, "Ten Tips for Designing a Consumer Friendly Downtown," Planning Journal of the American Planning Association (April 2003) 24-27. Quotations from page 24 .

W.M. Brodey, "The Design of Intelligent Environments: Soft Architecture," Landscape, Autumn (1967) 8-12.

California Department of Public Works, Preliminary Studies for an Additional Bridge Across San Francisco Bay - Report 3/31/47 (1948). Partially reproduced in A. Szoboszlay "Conflict of Transportation Competitors" (1999) <http:// www.trainweb.org/mts/ctc/bridgerpt.html> Accessed June 1, 2004.

S. Chan-Magomedow, Pioniere der sowjetischen Architektur: der Weg zur neuen sowjetischen Architektur in den zwanziger und zu Beginn der dreißiger Jahre (Dresden: Verlag der Kunst, 1983). Quotation from page 581.

J. Coaffee and P. Healey, "My Voice, My Place: Tracking Transformations in Urban Governance," Urban Studies 40:10 (2003) 1979-1999.

Congrès Internationaux d'Architecture Moderne (CIAM), "Charta von Athen," in Le Corbusier, An die Studenten der Chart d'Athènes (Reinbeck, 1962). Quotation from page 119.

The Churchill Center, Winston Churchill Quotes (2002) <http://www. winstonchurchill.org/quotes.htm\#buildings> Accessed October 29, 2002.

T. Crowe, Crime Prevention through Environmental Design: Applications of Architectural Design and Space Management Concepts second edition (Boston, MA; Oxford: Butterworth-Heinemann, 2000).

R. Draper, Crime Prevention through Environmental Design (2002) $<\mathrm{http}: / /$ www.cpted.com.au/> Accessed February 14, 2003.

D. Efremenko, "Up the Participation Ladder: Problems of Public Involvement in Environmental and Technological Policy-Making," in A. Bamme, G. Getzinger, and B. Wieser, eds., Yearbook 2003 of the Institute for Advanced Studies on Science, Technology, and Society (Munich and Vienna: Profil, 2003).

ETTA Training, Workshop CPTED - Crime Prevention Through Environmental Design (2004) <http://www.safeguardingaustralia.org.au/Event_brochures/ CPTED_brochure.pdf> Accessed May 22, 2004. 
S.S. Fainstein, "New Directions in Planning Theory," Urban Affairs Review 35:4 (2000) 451-478. Quotation from page 458.

G. Feder, Die neue Stadt: Versuch der Begründung einer neuen Stadtplanungskunst aus der sozialen Struktur der Bevölkerung (Berlin: Springer, 1939).

A. Feenberg, "Subversive Rationalization: Technology, Power, and Democracy," in A. Feenberg, ed., Technology and the Politics of Knowledge (Bloomington: Indiana University Press, 1995). Quotation from page 12.

R. Fishman, Urban Utopias in the Twentieth Century: Ebenezer Howard, Frank Lloyd Wright, and Le Corbusier (New York: Basic Books, 1977). Quotation from page 4.

G.H. Friedman, Canal Street: A Street Railway Spectacular (2004) <http://www. faculty.cs.uiuc.edu/ friedman/canal/Canal.htm> Accessed June 142004.

H-G. Gadamer, Truth and Method (London: Sheed and Ward, 1975). Quotation from 273.

A. Giddens, The Constitution of Society: Outline of the Theory of Structuration (Berkeley: University of California Press, 1984).

B. Grönlund, "The Civitas of Seeing and the Design of Cities: On the Urbanism of Richard Sennett," (1997) <http://hjem.get2net.dk/gronlund/Sennett_ny_ tekst_97kort.html> Accessed April 3, 2005.

P. Healey, "Creativity and Urban Governance: An Institutionalist Perspective" (2003) $<$ http://www.citymined.org/glocalbruXel/papers/patsyhealey.pdf> Accessed April 3, 2005.

P. Hertle, Bavarian State Department for Forestry, Personal Communication, May 22, 2004.

T.P. Hughes, "The Seamless Web: Technology, Science, et Cetera," in B. Elliott, ed., Social Studies of Science (Edinburgh: Edinburgh University Press, 1988).

J. Hunt and B. Wynne, "Forums for Dialogue: Developing Legitimate Authority through Communication and Consultation: A Contract Report for Nirex (Draft)," (2000) <http://domino.lancs.ac.uk/ieppp/Home.nsf/ByDocID/A2A4D62EF8B04 6BA80256A8900751AF8/\$FILE/forums + for + dialogue.doc> Accessed March 16, 2005. Quotation from page 17.

International Security Management \& Crime Prevention Institute, CPTED Workshop: Level 1 Residential (no year) <http://www.cpted.com.au/programs/ cptedres/intro.html> Accessed May 13, 2004.

D. Jacobs, "Met je winkelkar heel de stad door," Het Belang van Limburg (November 16, 1996). Quotation from page 9.

J. Jacobs, The Death and Life of Great American Cities (New York: Random House, 1961). Quotation from page 424, 429, 419, 420, 433. 
J. Jacobs, The Death and Life of Great American Cities (New York: Vintage Books, 1989). Quotations from page 433.

J. Jacobs, The Death and Life of Great American Cities (New York and Toronto: Random House, 1993). Quotation from the inside flap.

B. Joerges, Gebaute Umwelt und Verhalten. Über das Verhältnis von Technikwissenschaften und Sozialwissenschaften am Beispiel der Architektur und der Verhaltenstheorie (Baden-Baden: Nomos, 1977). Quotation from page 12.

B. Joerges, "Do Politics Have Artifacts?" Social Studies of Science 29:3 (1999) $411-431$.

B. Joerges, "Brücken, Busse, Autos und andere Verkehrsteilnehmer: Zur Repräsentation und Wirkung städtischer Artefakte," in G. Schmidt, ed., Technik und Gesellschaft, Jahrbuch Bd. 10, Automobil und Automobilismus (Frankfurt: Main Campus, 1999) 197-218.

A. Knie, and L. Marz, "Die Stadtmaschine. Zu einer Raumlast der Organisierten Moderne," Discussion Paper FS-II 97-108 (Berlin: Wissenschaftszentrum, 1997) <http://bibliothek.wZ-berlin.de/pdf/1997/ii97-108.pdf> Accessed June 13, 2004.

S. Kostof, The City Assembled: The Elements of Urban Form Through History (Boston, New York, London: Bulfinch Press, 1999). Quotation from page 125.

P.H. Kramer, "Gemeinbedarf" (2004) <http://www.people.freenet.de/PeterKramer/ PHKBASSG.htm> Accessed May 30, 2004.

L.H. Lapham, "Introduction to the MIT Press Edition: The Eternal Now," in M. McLuhan, Understanding Media: The Extensions of Man (Cambridge, MA: MIT Press, 1994). Quotation from page xxi.

B. Latour, "Where Are the Missing Masses? The Sociology of a Few Mundane Artefacts," in W.E. Bijker and J. Law, eds., Shaping Technology/Building Society: Studies in Sociotechnical Change (Cambridge, MA: MIT Press, 1992) 225-264.

B. Latour, "Which Politics for Which Artifacts?" Domus (June 2004) <http:// www.ensmp.fr/ latour/presse/presse_art/GB-06\%20DOMUS\%2006-04.html> Accessed June 14, 2004.

Le Corbusier, "Guiding Principles of Town Planning," in U. Conrads, ed., Programs and Manifestos of 20th Century Architecture (Cambridge, MA: MIT Press, 1990).

Y.S. Lincoln and E.G. Guba, Naturalistic Inquiry (Sage: Beverly Hills, CA, 1985).

T. McKay, "CPTED Tunnel Vision" (1998) <http://www.peelpolice.on.ca/ prevention/tunnel.htm> Accessed May 28, 2004.

T. McKay, "Modular Lotting: The Trewlany Experience" (1999) <http://www. peelpolice.on.ca/pdf-files/Trewlany.pdf> Accessed June 11, 2004. 
M. Mehaffy, "Codes and the Architecture of Life," Katarxis $N^{\circ} 3$ (2004) <http:// www.katarxis3.com/Mehaffy_Codes.htm> Accessed April 2, 2005.

M. Mehaffy, "The Kind of Problem Architecture Is," Katarxis $N^{\circ} 3$ (2004) <http:// www.katarxis3.com/Jacobs.htm> Accessed April 2, 2005.

J.S. Mill, Gesammelte Werke, trans. by T. Gomperz X (Aalen: Scientia, 1968). Quotation from page 160.

S. Moore, Technology and Place: Sustainable Architecture and the Blueprint Farm (Austin, TX: University of Texas Press, 2001).

S. Moore and R. Brand, "The Banks of Frankfurt and the Sustainable City," The Journal of Architecture 8:1 (2003) 3-24. Quotation from page 19.

R.H. Moos, Evaluating Correctional and Community Settings (New York: John Wiley \& Sons, 1975). Quotation from page 211.

T. More, Utopia (Basel, 1518) <http://www.ub.uni-bielefeld.de/diglib/more/ utopia/> Accessed November 10, 2004.

T. More, Utopia - 1556 Edition, trans. by R. Robynson (Boston: Bedford, 1999).

L. Mumford, "What is a City?" originally published in Architectural Record, LXXXII (November 1947). Sections reprinted in: R.T. LeGates and F. Stout, ed., The City Reader second edition (London: Routledge, 2000). Quotation from page 96.

Ministerie van de Vlaamse Gemeenschap, Afdeling Wegen en Verkeer Limburg, De Groene Boulevard in Hasselt: Vlaanderen. Een duurzame oplossing voor mobiliteit in de stad (2001). Quotation from page 29.

C. Norberg-Schulz, Logik der Baukunst, translated by J. Neugroeschel (Berlin, Frankfurt: Ullstein, 1965).

H. Osmond, "Function as the Basis of Psychiatric Ward Design," Mental Hospitals 8 (1957) 23-29.

PBS - Public Broadcasting Service, "Learning Adventures in Citizenship - Episode 7 - Topic 3 - Landmark Preservation," (N.D.) <http://www.pbs.org/wnet/newyork/ laic/episode7/topic3/e7_t3_s5-lp.html> Accessed April 2, 2005.

B. Pfaffenberger, “Technological Dramas," Science, Technology \& Human Values 17:3 (1992) 282-312.

H. Rohracher, "Between Innovation and Diffusion: The Importance of Users in Shaping Environmental Technologies," Proceedings of the International Summer Academy on Technology Studies: User Involvement in Technological Innovation (Graz: IFZ, 2001) 223-234 <http://www.ifz.tugraz. ac.at/sumacad/ 01/sa01_rohracher.pdf> Accessed November 13, 2002.

C. Schmitt, “Abgeblitzt!” Die Zeit (January 8 2004) 56. 
R. Sennett, The Uses of Disorder: Personal Identity and City Life (New York and London: Norton Paperback, 1992). Quotations from pages 6, 7.

E. Shove, "Sustainability, System Innovation, and the Laundry" (2002) <http:// www.comp.lancs.ac.uk/sociology/papers/shove-sustainability-system-innovation.pdf> Accessed March 16, 2005. Quotation from page 9.

B.F. Skinner, "Freedom and the Control of Men," The American Scholar 25 (Winter 1955-56) 47-65. Quotation from page 60.

B.F. Skinner, Beyond Freedom and Dignity (New York: Knopf, 1971).

B. Snell, "The Streetcar Conspiracy: How General Motors Deliberately Destroyed Public Transit," <http://www.tompaine.com/feature.cfm/ID/4518, 2001> (2001) Accessed March 22, 2005.

R. Sommer, Personal Space: The Behavioral Basis of Design (Englewood Cliffs, NJ: Prentice-Hall, 1969).

R. Sommer, Social Design: Creating Buildings with People in Mind (Englewood Cliffs, NJ: Prentice-Hall, 1983). Quotation from page 7.

M. Spott, "Vorbild Niederlande: Schöner: Und Sicherer Radeln," BUNDmagazin 5:1 (2005) B10 68a.

S. Stevaert, Deputy Prime Minister of the Flemish Government, Personal Interview (Brussels, December 6, 2001).

A. Szoboszlay, "Conflict of Transportation Competitors" (1999) <http://www. trainweb.org/mts/ctc/index.html> Accessed June 5, 2004.

S. Wallman, "The Diversity of Diversity: Implications of the Form and Process of Localized Urban Systems," Nota di lavoro 76 (2003) <http://www.feem.it/NR/ rdonlyres/B0FBE859-C93F-4BD2-9CCF-15A4EE7BD064/955/7604.pdf> Accessed April 3, 2005. Quotation from page 3.

W. Weaver, "Science and Complexity," A Quarter Century in the Natural Science: The Rockefeller Foundation Annual Report (New York: The Rockefeller Foundation, 1958).

L. Winner, "Do Artifacts Have Politics?” Daedalus 109:1 (Winter 1980) 121-136.

G. Woodgate and M. Redclift, "From a 'Sociology of Nature' to Environmental Sociology: Beyond Social Construction," Environmental Values 7 (1998) 3-24.

S. Woolgar and G. Cooper, "Do Artefacts Have Ambivalence? Moses' Bridges, Winner's Bridges, and Other Urban Legends in S\&TS," Social Studies of Science 29:3 (June 1999) 433-449.

O. Yiftachel, "The Dark Side of Modernism: Planning as Control of an Ethnic Minority," in S. Watson and K. Gibson, eds., Postmodern Cities and Spaces (Oxford: Basil Blackwell, 1994). 
